\title{
PENGATURAN PERSEDIAAN BERAS DI PERUM BULOG DIVRE SULTENG DENGAN METODE ECONOMIC ORDER QUANTITY (EOQ)
}

\author{
Nildawati ${ }^{1}$, R. Ratianingsih ${ }^{2}$, A. Sahari ${ }^{3}$ \\ 1Program Studi Matematika Jurusan Matematika FMIPA Universitas Tadulako \\ JalanSoekarno-Hatta Km. 09 Tondo, Palu 94118, Indonesia. \\ 1nianilda67535@gmail.com, 2ratianingsih@yahoo.com, 3agusmansaharii@yahoo.com
}

\begin{abstract}
Perum BULOG of Central Sulawesi Division is a national rice logistic company that its responsibility is to guarantee the sufficiency to meet the rice needs. Perum BULOG also responsible to keep rice price stability. One of the rice price component is the inventory costs that need to be managed. In this research the management is refered to the rice scheme demand of four storages, that are Olaya, Lawanga, Jaya Kencana Toili and Galang. This study uses $\mathrm{EOQ}$ (Economic Order Quantity) that consist of five priorities, that are determining the of economical order, determining the amount of safety stock, determining the maximum inventory quantities, determining the reorder point and determining total inventory cost. The results showed that the number of economical order storage of Olaya is $1.817 .120,57 \mathrm{~kg} /$ message, Lawanga is $1.893 .400,78 \mathrm{~kg} / \mathrm{message}$, Jaya Kencana Toili is $1.575 .543,38$ $\mathrm{kg} / \mathrm{messages}$ and Galang is $1.578 .742,75 \mathrm{~kg} / \mathrm{message}$. The total Inventory Security for Olaya is $32.371,28 \mathrm{~kg}$, Lawanga is $41.020,07 \mathrm{~kg}$, Jaya Kencana Toili is $30.630,61 \mathrm{~kg}$, and Galang is $57.307,99 \mathrm{~kg}$. The maximum inventory for Olaya is $1.849 .491,85 \mathrm{~kg}$, Lawanga is $1.934 .420,85 \mathrm{~kg}$, Jaya Kencana Toili is $1.606 .173,99 \mathrm{~kg}$, and Galang is $1.636 .050,74 \mathrm{~kg}$. The reorder point is proposed when rice stock of Olaya reaches $323.664,52 \mathrm{~kg}$, Lawanga reaches $357.282,87 \mathrm{~kg}$, Jaya Kencana Toili reaches $249.620,29 \mathrm{~kg}$ and Galang reaches $277.188 \mathrm{~kg}$. The total inventory cost that use Economic Order Quantity is Rp. 2.507.626,39 for Olaya, Rp. 2.612.893,07 for Lawanga, Rp.2.174.249 ,87 for Jaya Kencana Toili, and Rp 2.178.665,00 for Galang. The Efficiency cost of rice supplies BULOG Division is Rp.40.405,29 for Olaya, Rp. 719.256,02 for Lawanga, Rp. 51187.63 for Jaya Kencana Toili, and Rp. 153.528,73 for Galang. These result gives greatest efficiency at the cost of supplies of Perum BULOG Division Central Sulawesi for Lawanga $22 \%$ as much.
\end{abstract}

Keywords : Economic Order Quantity, Inventory, Storages

\section{ABSTRAK}

Perum BULOG Divre Sulawesi Tengah adalah perusahaan logistik nasional yang bertanggung jawab menjamin persediaan beras untuk memenuhi kebutuhan masyarakat.Perum BULOG juga bertanggung jawab untuk menjaga stabilitas harga beras.Salah satu komponen harga beras adalah biaya persediaan yang perlu dikelolah.Dalam penelitian ini Pengaturan dilakukan berdasarkan empat alur pengadaan beras Gudang Olaya, Lawanga, Jaya Kencana Toili dan Galang. Penelitian ini menggunakan metode EOQ (Economic Order Quantity) yang terdiri dari 5 prioritas, menentukan pengaturan yang ekonomis, menentukan jumlah persediaan pengaman, menentukan jumlah persediaan maksimum, menentukan titik pemesanan kembali dan menentukan besarnya biaya persediaan. 
Hasil penelitian menunjukkan bahwa pemesanan yang ekonomis untuk Gudang Olaya adalah 1.817.120,57 kg/pesan, Lawanga adalah 1.893.400,78 kg/pesan, Jaya Kencana Toili adalah 1.575.543,38 kg/pesan dan Galang adalah $1.578 .742,75 \mathrm{~kg} /$ pesan. Total Persediaan pengaman untuk Gudang Olaya adalah 32.371,28 kg, Lawanga adalah 41.020,07 kg, Jaya Kencana Toili adalah 30.630,61 kg, dan Galang adalah 57.307,99 kg. Persediaan maksimum untuk Olaya adalah 1.849.491,85 kg, Lawanga adalah 1.934.420,85 kg, Jaya Kencana Toili adalah 1.606.173,99 kg, dan Galang adalah $1.636 .050,74 \mathrm{~kg}$. Titik pemesanan kembali dilakukan saat stok beras pada Gudang Olaya mencapai 323.664,52 kg, Lawanga mencapai 357.282,87 kg, Jaya Kencana Toili mencapai $249.620,29 \mathrm{~kg}$ dan Galang mencapai $277,188 \mathrm{~kg}$. Total biaya persediaan yang menggunakan Economic Order Quantity untuk Gudang Olaya adalah Rp 2.507.626,39, Lawanga Rp 2.612.893,07, Jaya Kencana Toili Rp 2.174.249, 87, dan Galang Rp 2.178.665,00 untuk. Hasil tersebut memberikan implikasi terhadap efisiensi terbesar pada biaya persediaan Perum BULOG Divre Sulawesi Tengah untuk Gudang Lawanga sebesar $22 \%$.

Kata kunci : Economic Order Quantity, Persediaan, Gudang

\section{PENDAHULUAN}

Pangan merupakan kebutuhan dasar utama bagi manusia yang harus dipenuhi setiap saat.Hal tersebut yang mendasari terbitnya UU No. 7/1996 tentang Pangan.Firdaus.2008 (dalam Trisilawaty. 2011), mengemukakan bahwa pangan di Indonesia identik dengan beras karena beras merupakan makanan pokok utama.Gangguan pada ketahanan pangan (beras) seperti kekurangan ketersediaan beras dan kenaikkan harga beras dapat memicu kerawanan sosial, ketidakstabilan ekonomi dan politik serta secara menyeluruh dapat mengganggu stabilitas nasional.Dengan pertimbangan pentingnya beras tersebut, pemerintah selalu berupaya untuk menjaga ketersediaanberas sepanjang tahun, distribusi beras yang merata, harga beras yang stabil serta meningkatkan ketahanan pangannya dari produksi dalam negeri (swasembada beras).

Ketahanan pangan baik bagi individu, rumah tangga, maupun komunitas merupakan hak azasi manusia. Dalam ketahanan pangan, terdapat aspek Supply yang mencakup proses produksi dan distribusi. Ketersediaan beras erat kaitannya dengan produksi padi para petani. Jika cuaca mendukung, maka produksi padi yang dihasilkan akan baik dan berlimpah. Namun, jika cuaca tidak mendukung, biasa mengakibatkan gagal panen sehingga produksi padi tidak maksimal. Kondisi tersebut mencerminkan perlunya pengaturan persediaan beras yang mampu memenuhi kebutuhan masyarakat.

Persediaan beras pada setiap Perum BULOG sangat penting. Tanpa adanya persediaan, Perum BULOG akan dihadapkan pada resiko bahwa pada suatu waktu tidak dapat memenuhi permintaan masyarakat. Persediaan beras harus dapat memenuhi kebutuhan rencana produksi.Masalah penentuan besarnya persediaan merupakan masalah yang penting bagi perusahaan. Kesalahan dalam menentukan besarnya investasi (modal yang tertanam) dalam persediaan akan menekan keuntungan perusahaan. Adanya persediaan bahan baku yang terlalu besar dibandingkan dengan kebutuhan perusahaan akan menambah beban bunga, biaya pemeliharaan dan biaya penyimpanan dalam gudang, serta kemungkinan terjadinya penyusutan dan 
kualitas yang tidak dapat dipertahankan, sehingga akan mengurangi keuntungan perusahaan. Demikian pula sebaliknya, persediaan beras yang terlalu kecil dalam perusahaan akan mengakibatkan kemacetan dalam produksi, sehingga perusahaan akan mengalami kerugian.

Maka dari itu pemilihan metode dalam pengaturan persediaan beras sangat penting dilakukan karena merupakan salah satu upaya Perum BULOG untuk meminimalkan biaya produksi dan operasi. Metode Economic Order Quantity merupakan salah satu metode yang dapat digunakan untuk mengelola persediaan beras. Metode ini banyak digunakan karena mengatur persediaan berdasarkan penentuan banyaknya pesanan yang ekonomis, persediaan pengaman, persediaan maksimum, dan penentuan titik pemesanan kembali.Tingkat persediaan yang optimal memungkinkan kerugian yang ditimbulkan akibat kekurangan dan kelebihan persediaan dapat ditekan seminimal mungkin.

\section{METODE PENELITIAN}

Penelitian dilakukan sesuai prosedur dibawah ini :

1. Memulai penelitian.

2. Pengumpulan data yang didapatkan dari dari Perum BULOG Divre Sulteng

3. Implementasi metode Economic Order Quantity (EOQ)

4. Hasil perhitungan persediaan beras perum BULOG Divre Sulteng tahun 2016 berdasarkan metode Economic Order Quantity (EOQ).

5. Kesimpulan.

6. Selesai.

III. HASIL DAN PEMBAHASAN

\subsection{Pengumpulan Data}

Data penelitian ini diambil dariPerum BULUG Divre Sulteng berdasrkan alur pengadaan beras tahun 2016 untuk Gudang Olaya, Lawanga, Jaya Kencana Toili, dan galangdengan kriteria yang diberikan oleh Perum BULUG Divre Sulteng yaitu, pengadaan beras dalam satu tahun, biaya pemesanan per pesan, biaya penyimpanan per unit, harga per kilogram, dan waktu tunggu/Lead time.

Perum BULOG Divre Sulteng yang berpusat di Palu memiliki 3 Sub Divre, yaitu Poso, Luwuk dan Tolitoli, dengan 4 gudang beras BULOG (GBB) terbesar yang berlokasi di Olaya, Lawanga, Jaya Kencana Toili dan Galang. Pengadaan beras yang dilakukan BULOG dapat melalui dua saluran dalam penyerapan produksi petani yaitu satuan tugas (SATGAS), Unit Pengolahan Gabah dan Beras (UPGB). Kedua saluran tersebut membeli gabah langsung dari petani dengan patokan HPP. Alur pengadaan beras dimulai dari Divre Sulteng meminta Sub Divre untuk melakukan pengadaan beras. Setelah Sub Divre menerima perintah dari Divre, kemudian Sub Divre melakukan negosiasi kontrak dengan Mitra Kerja. Jika kontrak disetujui, maka Sub Divre akan mengirim Surat Perintah Terima Barang (SPTB) kepada gudang. 
Selanjutnya, Mitra Kerja akan mengirim beras ke gudang berdasarkan kontrak yang disetujui. Sebelum menerima beras, petugas survey di gudang akan mengecek kelayakan beras (survey kualitas) tersebut. Setelah itu, gudang akan menerima beras tersebut dan membuat laporan penerimaan barang. Selain itu untuk menjaga kekurangan persediaan pada gudang, pengadaan beras juga dilakukan melalui pertukaran antar Divre dan Sub Divre (Move Reg).Alur tersebut disusun dalam skema pada gambar 1.Dalam penelitian ini diperlukan data biaya pemesanan, biaya penyimpanan, harga per liter, dan data pengadaan beras pada masingmasing gudang yang secara berturut-turut dinyatakan pada tabel 1 , tabel 2 , tabel 3 , tabel 4 , dan tabel 5 .

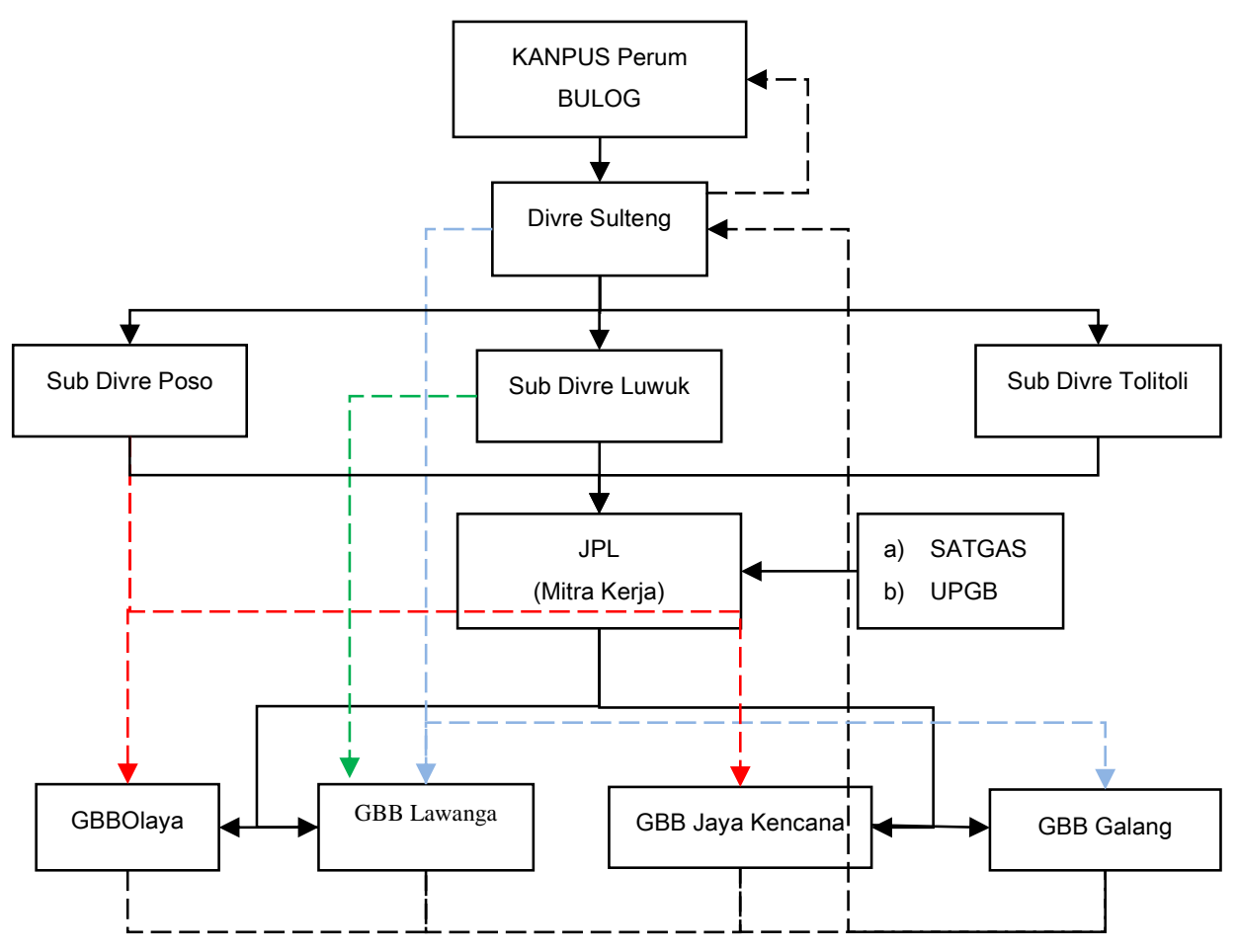

Gambar 1 : Alur Pengadaan Beras GBB Olaya, GBB Lawanga, GBB Jaya Kencana Toili, GBB Galang Tahun 2016

Keterangan:

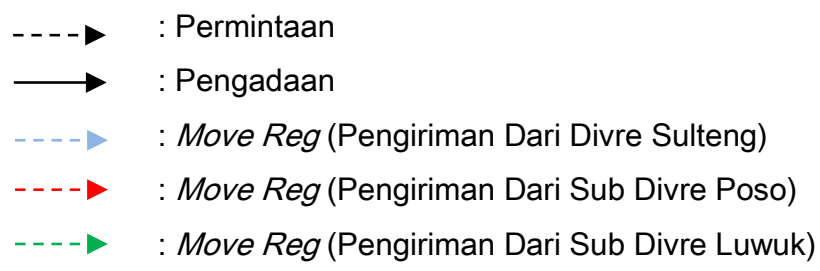


Tabel 1 : Data Biaya Persediaan Per satu kali pesan untuk Gudang Olaya, Lawanga, Jaya Kencana Toili, dan Galang

\begin{tabular}{|c|c|}
\hline Biaya pemesanan & Rp. 150.000 \\
\hline Biaya Penyimpanan & $1,38 \%$ \\
\hline Harga Perliter & Rp. 7.300 \\
\hline Lead Time/waktu tunggu & 7 Hari \\
\hline
\end{tabular}

Table 2 : Pengadaan Beras GBB Olaya Tahun 2016

\begin{tabular}{|c|c|c|c|c|c|}
\hline & \multicolumn{5}{|c|}{ Gudang Olaya } \\
\hline & Bulan & Frekuensi & $\begin{array}{c}\text { Sub Divre Poso } \\
\text { (Move Reg)/(kg) }\end{array}$ & $\begin{array}{c}\text { Mitra } \\
\text { Kerja/(kg) }\end{array}$ & $\begin{array}{c}\text { Jumlah Persediaan di } \\
\text { Gudang/(kg) }\end{array}$ \\
\hline 1 & Januari & 1 & 6.025 & - & 6.025 \\
\hline 2 & Februari & & - & - & - \\
\hline 3 & Maret & 1 & - & 305.165 & 305.165 \\
\hline 4 & April & & - & - & $170.405,00$ \\
\hline 5 & Mei & 2 & 200.000 & 308.560 & $678.965,00$ \\
\hline 6 & Juni & & - & - & $561.410,00$ \\
\hline 7 & Juli & 1 & - & 47.145 & $608.555,00$ \\
\hline 8 & Agustus & & - & - & $428.765,00$ \\
\hline 9 & Septembe & 1 & - & 2.111 .835 & $2.540 .600,00$ \\
& $r$ & & - & 423.920 & $2.964 .520,00$ \\
\hline 10 & Oktober & 1 & - & 34.175 & $3.083 .695,00$ \\
\hline 11 & November & 2 & 85.000 & 757.065 & $3.840 .760,00$ \\
\hline 12 & Desember & 1 & - & $\mathbf{3 . 9 8 7 . 8 6 5}$ & $\mathbf{1 5 . 1 8 8 . 8 6 5}$ \\
\hline & Jumlah & 10 & 291.025 & $1.265 .738,75$ \\
\hline \multicolumn{7}{|l|}{ Rata-rata } \\
\hline
\end{tabular}

Sumber : Perum BULOG Divre Sulteng

Table 3 : Pengadaan Beras GBB Lawanga Tahun 2016

\begin{tabular}{|c|c|c|c|c|c|c|}
\hline & \multicolumn{7}{|c|}{ Gudang Lawanga } \\
\hline & Bulan & Frekuensi & $\begin{array}{c}\text { Divre Sulteng } \\
(\text { Move } \\
\text { Reg)/(kg) }\end{array}$ & $\begin{array}{c}\text { Sub Divre } \\
\text { Luwuk (Move } \\
\text { Reg)/(kg) }\end{array}$ & $\begin{array}{c}\text { Mitra } \\
\text { Kerja/(kg) }\end{array}$ & $\begin{array}{c}\text { Jumlah } \\
\text { Persediaan di } \\
\text { Gudang/(kg) }\end{array}$ \\
\hline 1 & Januari & 2 & 200.000 & -- & 1.260 .357 & 1.460 .357 \\
\hline 2 & Februari & --- & --- & --- & --- & 854.792 \\
\hline 3 & Maret & --- & --- & --- & --- & 489.341 \\
\hline 4 & April & 1 & --- & 46.110 & -- & $535.450,90$ \\
\hline 5 & Mei & 3 & 34.000 & 160.000 & 200.814 & $930.264,90$ \\
\hline 6 & Juni & 2 & --- & 6.000 & 190.381 & $1.126 .644,90$ \\
\hline 7 & Juli & 1 & --- & --- & 1.705 & $1.128 .349,60$ \\
\hline
\end{tabular}




\begin{tabular}{|c|c|c|c|c|c|c|}
\hline 8 & Agustus & --- & --- & --- & -- & $992.864,60$ \\
\hline 9 & September & --- & --- & --- & --- & $864.424,60$ \\
\hline 10 & Oktober & 3 & 200.000 & 500.000 & 762.160 & $2.326 .585,50$ \\
\hline 11 & November & 3 & 50.000 & 150.000 & 270.130 & $2.796 .715,50$ \\
\hline 12 & Desember & 3 & 49.000 & 51.000 & 88.340 & $2.985 .055,04$ \\
\hline & Jumlah & $\mathbf{1 8}$ & $\mathbf{5 3 3 . 0 0 0}$ & $\mathbf{9 1 3 . 1 1 0}$ & $\mathbf{2 . 7 7 3 . 8 8 7}$ & 16.490 .846 \\
\hline & \multicolumn{5}{|c|}{ Rata-rata } & $1.374 .237,167$ \\
\hline
\end{tabular}

Sumber : Perum BULOG Divre Sulteng

Table 4: Pengadaan beras GBB Jaya Kencana Toili Tahun 2016

\begin{tabular}{|c|c|c|c|c|c|}
\hline & \multicolumn{5}{|c|}{ Gudang Jaya Kencana Toili } \\
\hline & Bulan & Frekuensi & $\begin{array}{c}\text { Sub Divre Poso } \\
\text { (Move Reg) /(kg) }\end{array}$ & Mitra Kerja/(kg) & $\begin{array}{c}\text { Jumlah Persediaan di } \\
\text { Gudang/(kg) }\end{array}$ \\
\hline 1 & Januari & 2 & 100.000 & 349.135 & 449.135 \\
\hline 2 & Februari & --- & --- & --- & 408.615 \\
\hline 3 & Maret & --- & --- & --- & 220.325 \\
\hline 4 & April & --- & --- & 296.370 & $27.005,00$ \\
\hline 5 & Mei & 2 & 90.000 & 670.155 & $1.083 .530,00$ \\
\hline 6 & Juni & --- & --- & --- & $1.052 .290,00$ \\
\hline 7 & Juli & --- & -- & -- & $1.165 .725,00$ \\
\hline 8 & Agustus & 1 & 113.435 & 375.365 & $1.568 .090,00$ \\
\hline 9 & September & 1 & --- & 49.840 & $1.617 .930,00$ \\
\hline 10 & Oktober & 1 & --- & -- & $1.077 .770,00$ \\
\hline 11 & November & --- & --- & 987.190 & $2.334 .960,00$ \\
\hline 12 & Desember & 2 & 270.000 & 2.728 .055 & 11.418 .750 \\
\hline & Jumlah & 9 & 573.435 & & $951.562,5$ \\
\hline & & & Rata-rata & & \\
\hline
\end{tabular}

Sumber : Perum BULOG Divre Sulteng

Table 5: Pengadaan Beras GBB Galang Tahun 2016

\begin{tabular}{|c|c|c|c|c|c|}
\hline & \multicolumn{5}{|c|}{ Gudang Galang } \\
\hline & Bulan & Frekuensi & $\begin{array}{c}\text { Divre Sulteng } \\
\text { (Move Reg) /(kg) }\end{array}$ & $\begin{array}{c}\text { Mitra } \\
\text { Kerja/(kg) }\end{array}$ & $\begin{array}{c}\text { Jumlah Persediaan di } \\
\text { Gudang/(kg) }\end{array}$ \\
\hline 1 & Januari & 2 & 50.000 & 1.904 .456 & 1.954 .456 \\
\hline 2 & Februari & --- & --- & --- & 775.881 \\
\hline 3 & Maret & --- & --- & --- & 775.881 \\
\hline 4 & April & --- & & --- & $515.376,00$ \\
\hline 5 & Mei & --- & --- & --- & $484.341,00$ \\
\hline 6 & Juni & --- & --- & --- & $275.016,00$ \\
\hline 7 & Juli & 1 & -- & 772.870 & $1.047 .886,00$ \\
\hline 8 & Agustus & 1 & 185.073 & --- & $1.232 .959,00$ \\
\hline
\end{tabular}




\begin{tabular}{|c|c|c|c|c|c|}
\hline 9 & September & -- & --- & -- & $1.212 .394,00$ \\
\hline 10 & Oktober & --- & --- & $1.032 .424,00$ \\
\hline 11 & November & --- & --- & --- & $821.794,00$ \\
\hline 12 & Desember & 1 & --- & 514.970 & $1.336 .764,00$ \\
\hline & Jumlah & 5 & 185.073 & 3.192 .296 & 11.465 .172 \\
\hline & \multicolumn{5}{|c|}{ Rata-rata } \\
\hline
\end{tabular}

Sumber : Perum BULOG Divre Sulteng

\subsection{Economic Order Quantity (EOQ)}

Data pada sesi 3.1 diolah menggunakan metode Economic Order Quantity(EOQ) sebagai berikut:

1. Pengaturan Persediaan Beras yang ekonomis

$E O Q=\sqrt{\frac{2 \times A \times P}{C}}$ dimana, EOQmenyatakan Jumlah pesanan ekonomis untuk satu kali pesan dalam satuan $(\mathrm{kg})$, A adalah Jumlah kebutuhan beras dalam satu periode tertentu (kg), Padalah Biaya pemesanan setiap kali pesan (Rp), dan C adalah Biaya penyimpanan yang dinyatakan dalampresentasedari persediaan rata-rata (\%)(Gitosudarmo.1999).

2. Menghitung Persediaan Pengaman (Safety Stock)

$S=Z \times \sigma$ dimana, $S=$ persediaan pengaman(Safety stock), $Z=$ Standar normal deviasi $\sigma=\sqrt{\frac{\sum(x-\bar{x})^{2}}{n}} n=$ banyak data

3. Menghitung Persediaan Maksimum (Maksimum Inventory)

Maximum Inventory $(\mathrm{MI})=\mathrm{S}+\mathrm{EOQ}$ dimana,S : Persediaan pengaman $(\mathrm{kg}), \mathrm{EOQ}$ : jumlah pesanan yang ekonomis (kg) (Assauri. 1999).

4. Menentukan Titik Pemesanan Kembali (Reorder Point)

Reorder Point $=\mathrm{L}+\mathrm{S}$ dimana, $\mathrm{L}:$ Penyaluran selama waktu tunggu $(\mathrm{kg}), \mathrm{S}:$ Persediaan pengaman (kg) (Riyanto. 2001).

5. Menentukan Besarnya Biaya Persediaan(Total Inventory Cost)

$T I C=\sqrt{2 A P C}$ dimana, TIC menyatakan Total Inventory Cost (total biaya persediaan), A adalahJumlah kebutuhan beras dalam satu periode, $P$ adalah Biaya $(R p)$ setiap kali pemesanan, dan $\mathrm{C}$ adalah Biaya penyimpanan per karung beras

\subsection{Implementasi Metode Economic Order Quantity(EOQ)}

1. Menghitung Frekuensi Pemesanan Beras Menurut Metode EOQ

a. Gudang Olaya.

$$
E O Q=\sqrt{\frac{2 \times 15.188 .865 \times 150.000}{1,38}}=1.817 .120,57 \mathrm{~kg} / \text { Pesan }
$$


Frekunsi pemesanan selama 1 tahun $=\frac{15 \cdot 188.865}{1.817 \cdot 120,57}=8 \mathrm{kali}$

b. Gudang Lawanga

$E O Q=\sqrt{\frac{2 \times 16.490 .846 \times 150.000}{1,38}}=1.893 .400,78 \mathrm{~kg} /$ pesan

Frekunsi pemesanan selama 1 tahun $=\frac{16.490 .846}{1.893 .400,78}=9 \mathrm{kali}$

c. Gudang jaya kencana toili

$E O Q=\sqrt{\frac{2 \times 11.418 .750 \times 150.000}{1,38}}=1.575 .543,38 \mathrm{~kg} /$ pesan

Frekunsi pemesanan selama 1 tahun $=\frac{11.418 .750}{1.575 .543,38}=7 \mathrm{kali}$

d. Gudang Galang

$E O Q=\sqrt{\frac{2 \times 11.465 .172 \times 150.000}{1,38}}=1.578 .742,75 \mathrm{~kg} /$ pesan

Frekuensi pemesanan selama 1 tahun $=\frac{11.465 .172}{1.578 .742,75}=7 \mathrm{kali}$

2. Menghitung Persediaan Pengaman (Safety Stock)

Dengan menggunakan nilai EOQ pada masing-masing gudang, persediaan pengaman dihitung sebagai berikut :

a. Gudang Olaya

Tabel 6: Perhitungan Standar Deviasi Gudang Olaya

\begin{tabular}{|c|c|c|c|c|}
\hline & \multicolumn{4}{|c|}{ Gudang Olaya } \\
\hline & Bulan & Pasokan $(\boldsymbol{X})$ & $(\boldsymbol{X}-\overline{\boldsymbol{x}})$ & $(\boldsymbol{X}-\overline{\boldsymbol{x}})^{2}$ \\
\hline 1 & Januari & 6.025 & $-1.259 .713,75$ & 1,586878732222 \\
\hline 2 & Februari & --- & & \\
\hline 3 & Maret & 305.165 & $-960.573,75$ & 9,22701929222 \\
\hline 4 & April & $170.405,00$ & $-1.095 .333,75$ & 1,199756024444 \\
\hline 5 & Mei & $678.965,00$ & $-586.773,75$ & 3,44303433777 \\
\hline 6 & Juni & 561.410 .00 & $-704.328,75$ & 4,96078988111 \\
\hline 7 & Juli & $608.555,00$ & $-657.183,75$ & 4,31890481333 \\
\hline 8 & Agustus & $428.765,00$ & $-836.973,75$ & 7,00525058222 \\
\hline 9 & September & $2.540 .600,00$ & $1.274 .861,25$ & 1,625271207777 \\
\hline 10 & Oktober & $2.964 .520,00$ & $1.698 .781,25$ & 2,885857735555 \\
\hline 11 & November & $3.083 .695,00$ & $1.817 .956,25$ & 3,304964927777 \\
\hline 12 & Desember & $3.840 .760,00$ & $2.575 .021,25$ & 6,630734438888 \\
\hline & Jumlah & 15.188 .865 & & 46,18846197 \\
\hline & Rata-rata $(\bar{x})$ & $1.265 .738,75$ & & \\
\hline
\end{tabular}


Berdasarkan Tabel 6, di peroleh $\sigma=\sqrt{\frac{\sum(x-\bar{x})^{2}}{n}}=19.618,96$. Hasil tersebut memberikan standar deviasi yaitu $\sigma=19.618,96$, dan Perum BULOG Divre Sulteng menggunakan batas toleransi $\sigma=5 \%$ dibawah perkiraan dan diperoleh nilai standar normal deviasi (Z) adalah 1,65. Maka besarnya persediaan pengaman (safety stock) beras dapat dihitung dengan rumus sebagai berikut:

$S=Z \times \sigma$ dimana, $S$ menyatakan safety stock (persediaan pengaman), $Z$ adalah standar normal deviasi dan $\sigma$ adalah standar deviasi

$S=Z \times \sigma=32.371,28 \mathrm{~kg}$

b. Gudang Lawanga

Tabel 7: Perhitungan Standar Deviasi Gudang Lawanga

\begin{tabular}{|l|l|l|l|l|}
\hline & \multicolumn{4}{|c|}{ Gudang Lawanga } \\
\hline & Bulan & Pasokan $(\boldsymbol{X})$ & \multicolumn{1}{|c|}{$(\boldsymbol{X}-\overline{\boldsymbol{x}})$} & $(\boldsymbol{X}-\overline{\boldsymbol{x}})^{2}$ \\
\hline 1 & Januari & 1.460 .357 & $86.119,83$ & 7.416 .625 .636 \\
\hline 2 & Februari & 854.792 & $-519.445,167$ & 2,698232815 \\
\hline 3 & Maret & 489.341 & $-884.896,167$ & 7,830412264 \\
\hline 4 & April & $535.450,90$ & $-838.786,267$ & 7,035624017 \\
\hline 5 & Mei & $930.264,90$ & $-443.972,267$ & 1,971113739 \\
\hline 6 & Juni & $1.126 .644,90$ & $-247.592,267$ & 6,130193068 \\
\hline 7 & Juli & $1.128 .349,60$ & $-245.887,567$ & 6,046069561 \\
\hline 8 & Agustus & $992.864,60$ & $-381.372,567$ & 1,454450349 \\
\hline 9 & September & $864.424,60$ & $-509.812,567$ & 2,599088535 \\
\hline 10 & Oktober & $2.326 .585,50$ & $952.348,333$ & 9,069673474 \\
\hline 11 & November & $2.796 .715,50$ & $1.422 .478,333$ & 2,023444608 \\
\hline 12 & Desember & $2.985 .055,04$ & $1.610 .817,873$ & 2,59473422 \\
\hline & Jumlah & 16.490 .846 & & $7.416 .625 .685,45$ \\
\hline & Rata-rata $(\bar{x})$ & $1.374 .237,167$ & & \\
\hline
\end{tabular}

Berdasarkan Tabel 7, diperoleh, $\sigma=\sqrt{\frac{\sum(x-\bar{x})^{2}}{n}}=24.860,65$. Hasil tersebut memberikan standar deviasi yaitu $\sigma=24.860,65$, dan Perum BULOG Divre Sulteng menggunakan batas toleransi $\sigma=5 \%$ dibawah perkiraan dan diperoleh nilai standar normal deviasi (Z) adalah 1,65. Maka besarnya persediaan pengaman (safety stock) beras dapat dihitung dengan rumus sebagai berikut: $S=Z \times \sigma$ dimana, $S$ menyatakan safety stock (persediaan pengaman), $Z$ adalah standar normal deviasi dan $\sigma$ adalah standar deviasi

$$
S=Z \times \sigma=41.020,07 \mathrm{~kg}
$$


c. Gudang Jaya Kencana Toili

Tabel 8: Perhitungan Standar Deviasi Gudang Jaya Kencana Toili

\begin{tabular}{|c|c|c|c|c|}
\hline & \multicolumn{4}{|c|}{ Gudang Jaya Kencana Toili } \\
\hline & Bulan & Pasokan $(X)$ & $(X-\bar{x})$ & $(X-\bar{x})^{2}$ \\
\hline 1 & Januari & 449.135 & $-502.427,5$ & 2,524333928 \\
\hline 2 & Februari & 408.615 & $-542.947,5$ & 2,947919878 \\
\hline 3 & Maret & 220.325 & $-731.237,5$ & 5,347082814 \\
\hline 4 & April & $27.005,00$ & $-924.557,5$ & 8,548065708 \\
\hline 5 & Mei & $413.375,00$ & $-538.187,5$ & 2,896457852 \\
\hline 6 & Juni & $1.083 .530,00$ & $131.967,5$ & 1,741542106 \\
\hline 7 & Juli & $1.052 .290,00$ & $100.727,5$ & 1,014602926 \\
\hline 8 & Agustus & $1.165 .725,00$ & $214.162,5$ & 4,586557641 \\
\hline 9 & September & $1.568 .090,00$ & $616.527,5$ & 3,801061583 \\
\hline 10 & Oktober & $1.617 .930,00$ & $666.367,5$ & 4,440456451 \\
\hline 11 & November & $1.077 .770,00$ & $126.207,5$ & 1,592833306 \\
\hline 12 & Desember & $2.334 .960,00$ & $1.383 .397,5$ & 1,913788643 \\
\hline & Jumlah & 11.418 .750 & & 41,35470284 \\
\hline & Rata-rata $(\bar{x})$ & $951.562,5$ & & \\
\hline
\end{tabular}

Berdasarkan Tabel 8, diperoleh, $\sigma=\sqrt{\frac{\sum(x-\bar{x})^{2}}{n}}=18.564,01$. Hasil tersebut memberikan standar deviasi yaitu $\sigma=18.564,01$ dan Perum BULOG Divre Sulteng menggunakan batas toleransi $\sigma=5 \%$ dibawah perkiraan dan diperoleh nilai standar normal deviasi (Z) adalah 1,65. Maka besarnya persediaan pengaman (safety stock) beras dapat dihitung dengan rumus sebagai berikut: $S=Z \times \sigma$ dimana,S menyatakansafety stock (persediaan pengaman), $\quad Z$ adalahstandar normal deviasi dan $\sigma$ adalah standar deviasi $S=Z \times \sigma=30.630,61 \mathrm{~kg}$

d. Gudang Galang

Tabel 9: Perhitungan Standar Deviasi Gudang Galang

\begin{tabular}{|l|l|l|c|c|}
\hline & \multicolumn{4}{|c|}{ Gudang Galang } \\
\hline & Bulan & Pasokan $(\boldsymbol{X})$ & $(\boldsymbol{X}-\overline{\boldsymbol{x}})$ & $(\boldsymbol{X}-\overline{\boldsymbol{x}})^{\mathbf{2}}$ \\
\hline 1 & Januari & 1.954 .456 & 959,025 & 9,197289506 \\
\hline 2 & Februari & 775,881 & -179.550 & 3,22382025 \\
\hline 3 & Maret & 775,881 & -219.550 & 4,82022025 \\
\hline 4 & April & $515,376.00$ & -440.055 & 1,93648403 \\
\hline 5 & Mei & $484.341,00$ & -471.090 & 2,219257881 \\
\hline 6 & Juni & $275.016,00$ & -720.415 & 5,189977722 \\
\hline
\end{tabular}




\begin{tabular}{|l|l|l|l|l|}
\hline 7 & Juli & $1.047 .886,00$ & 92.455 & 8.547 .927 .025 \\
\hline 8 & Agustus & $1.232 .959,00$ & 277.528 & 7,702179078 \\
\hline 9 & September & $1.212 .394,00$ & 2.167 .825 & 4,699465231 \\
\hline 10 & Oktober & $1.032 .424,00$ & 76.993 & 5.927 .922 .049 \\
\hline 11 & November & $821.794,00$ & -133.637 & 1,785884777 \\
\hline 12 & Desember & $1.336 .764,00$ & 381.333 & 1,454148569 \\
\hline & Jumlah & 11.465 .172 & & $14.475 .849 .116,23$ \\
\hline & Rata-rata $(\bar{x})$ & 955.431 & & \\
\hline \multicolumn{5}{|l}{} \\
\hline
\end{tabular}

Berdasarkan Tabel 9, diperoleh, $\sigma=\sqrt{\frac{\sum(x-\bar{x})^{2}}{n}}=34.732,12$. Hasil tersebut memberikan standar deviasi yaitu $\sigma=34.732,12$, dan Perum BULOG Divre Sulteng menggunakan batas toleransi $\sigma=5 \%$ dibawah perkiraan dan diperoleh nilai standar normal deviasi (Z) adalah 1,65. Maka besarnya persediaan pengaman (safety stock) beras dapat dihitung dengan rumus sebagai berikut: $S=Z \times \sigma$ dimana, $S$ menyatakan safety stock (persediaan pengaman), $Z$ adalah standar normal deviasi dan $\sigma$ adalah standar deviasi $S=Z \times \sigma=57.307,99 \mathrm{~kg}$

3. Menghitung Persediaan Maksimum (maximum inventory) Dengan menggunakan nilai EOQ dan persediaan pengaman (s) perhitungan persediaan maksimum masing-masing gudang sebagai berikut :

a. Gudang Olaya

$$
(\mathrm{MI})=\mathrm{S}+\mathrm{EOQ}=1.849 .491,85 \mathrm{~kg}
$$

b. Gudang Lawanga

$$
(\mathrm{MI})=\mathrm{S}+\mathrm{EOQ}=1.934 .420,85 \mathrm{~kg}
$$

c. Gudang Jaya Kencana Toili

$$
(\mathrm{MI})=\mathrm{S}+\mathrm{EOQ}=1.606 .173,99 \mathrm{~kg}
$$

d. Gudang Galang

$$
(\mathrm{MI})=\mathrm{S}+\mathrm{EOQ}=1.636 .050,74 \mathrm{~kg}
$$

4. Pengaturan Titik pemesanan Kembali (reorder point)

Reorder Point $(\mathrm{ROP})=\mathrm{L}+\mathrm{S}$ untuk masing-masing gudang dihitung sebagai berikut :

a. Gudang Olaya

1) Perkiraan rata-rata kebutuhan perbulan $=$ $\frac{\text { jumlah pemesanan dalam satu tahun }}{\text { jumlahhari dalam satu tahun }}=41.613,32 \mathrm{~kg}$

2) Penyaluran selama waktu tunggu $(L)=7$ hari $\times$ rata-rata pemesanan perbulan $=291.293,24 \mathrm{~kg}$ 
3) Sehingga titik pemesanan kembali (reorder point) dapat dihitung sebagai berikut:

$$
\mathrm{ROP}=\mathrm{S}+\mathrm{L}=323.664,52 \mathrm{~kg}
$$

b. Gudang Lawanga

1) Perkiraan rata-rata kebutuhan perbulan $=$ $\frac{\text { jumlah pemesanan dalam satu tahun }}{\text { jumlahhari dalam satu tahun }}=45.180,4 \mathrm{~kg}$

2) Penyaluran selama waktu tunggu $(L)=7$ hari $\times$ rata-rata pemesanan perbulan $=316.262,8 \mathrm{~kg}$

3) Sehingga titik pemesanan kembali (reorder point) dapat dihitung sebagai berikut:

$\mathrm{ROP}=\mathrm{S}+\mathrm{L}=357.282,87 \mathrm{~kg}$

c. Gudang Jaya Kencana Toili

1) Perkiraan rata-rata kebutuhan perbulan $=$ $\frac{\text { jumlah pemesanan dalam satu tahun }}{\text { jumlahhari dalam satu tahun }}=31.284,24 \mathrm{~kg}$

2) Penyaluran selama waktu tunggu $(L)=7$ hari $\times$ rata-rata pemesanan perbulan $=218.989,68 \mathrm{~kg}$

3) Sehingga titik pemesanan kembali (reorder point) dapat dihitung sebagai berikut:

$\mathrm{ROP}=\mathrm{S}+\mathrm{L}=249.620,29 \mathrm{~kg}$

d. Gudang Galang

1) Perkiraan rata-rata kebutuhan perbulan $=$ $\frac{\text { jumlah pemesanan dalam satu tahun }}{\text { jumlahhari dalam satu tahun }}=31.411,43 \mathrm{~kg}$

2) Penyaluran selama waktu tunggu $(L)=7$ hari $\times$ rata-rata pemesanan perbulan $=219.880,01 \mathrm{~kg}$

3) Sehingga titik pemesanan kembali (reorder point) dapat dihitung sebagai berikut:

$\mathrm{ROP}=\mathrm{S}+\mathrm{L}=277.188 \mathrm{~kg}$

\section{Grafik Pengaturan Pemesanan Kembali Gudang Beras}

Berdasarkan perhitungan frekuensi pemesanan beras, perhitungan persediaan pengaman, perhitungan persediaan maksimum, dan penentuan titik pemesanan kembali pada sesi 4.2.1 - 4.2.4 dapat digambarkan grafik pengaturan persediaan beras di Perum BULOG Divre Sulteng untuk tiap-tiap gudang beras secara berturut-turut pada Gambar 2, Gambar 3, Gambar 4, dan Gambar 5 sebagai berikut: 
a. Gudang Olaya

Berdasarkan perhitungan frekuensi pemesana beras pada sesi 3.3 yang memberikan 8 kali pemesanan persediaan beras sebanyak 1.817.120,57 kg akan habis pada minggu ket $t_{1}=t_{2}=\ldots=t_{8}=\frac{12}{8}$ minggu (dalam 1 tahun $=12$ bulan).

Panjang satu kali pemesanan adalah $\frac{12}{8}=1.5$ bulan. Karena adanya lead time selama 1 minggu, maka Gudang Olaya perlu menyiapkan persediaan pengaman untuk permintaan selama 1 minggu, yaitu sebanyak $32.371,28 \mathrm{~kg}$. Jadi Gudang Olaya perlu melakukan pemesanan kembali sebesar 1.817.120,57 kg ketika jumlah persediaan beras mencapai $323.664,52 \mathrm{~kg}$.

\section{b. Gudang Lawanga}

Berdasarkan perhitungan frekuensi pemesana beras pada sesi 3.3 yang memberikan 9 kali pemesanan, persediaan barang sebanyak $1.893 .400,78 \mathrm{~kg}$ akan habis minggu ket $t_{1}=t_{2}=\ldots=t_{9}=\frac{12}{9}$ minggu (dalam 1 tahun $=12$ bulan).

Panjang satu kali pemesanan adalah $\frac{12}{9}=1,3$ bulan. Karena adanya lead time selama 1 minggu, maka Perum BULOG Divre Sulteng perlu menyiapkan persediaan pengaman untuk permintaan selama 1 minggu, yaitu sebanyak 41.020,07 kg. Jadi Gudang Lawanga perlu melakukan pemesanan kembali sebesar $1.893 .400,78 \mathrm{~kg}$ ketika jumlah persediaan beras mencapai $357.282,87 \mathrm{~kg}$.

\section{c. Gudang Jaya Kencana Toili}

Berdasarkan perhitungan frekuensi pemesanan beras pada sesi 3.3 yang memberikan 7 kali pemesanan, persediaan barang sebanyak $1.575 .543,38 \mathrm{~kg}$ akan habis minggu ket $t_{1}=t_{2}=\ldots=t_{7}=\frac{12}{7}$ minggu (dalam 1 tahun $=12$ bulan).

Panjang satu kali pemesanan adalah $\frac{12}{7}=1,7$ bulan. Karena adanya lead time selama 1 minggu, maka Perum BULOG Divre Sulteng perlu menyiapkan persediaan pengaman untuk permintaan selama 1 minggu, yaitu sebanyak $30.630,61 \mathrm{~kg}$. Jadi Gudang Jaya Kencana Toili perlu melakukan pemesanan kembali sebesar $1.575 .543,38 \mathrm{~kg}$ ketika jumlah persediaan beras mencapai $249.620,29 \mathrm{~kg}$.

\section{d. Gudang Galang}

Berdasarkan perhitungan frekuensi pemesanan beras pada sesi 3.3 yang memberikan 7 kali pemesanan, persediaan barang sebanyak $1.578 .742,75 \mathrm{~kg}$ akan habis minggu ket $t_{1}=t_{2}=\ldots=t_{7}=\frac{12}{7}$ minggu (dalam 1 tahun $=12$ bulan) .

Panjang satu kali pemesanan adalah $\frac{12}{7}=1$, Tbulan. Karena adanya lead time selama 1 minggu, maka Gudang Galang perlu menyiapkan persediaan 
pengaman untuk ermintaan selama 1 minggu, yaitu sebanyak $57.307,99 \mathrm{~kg}$. Jadi Gudang Galang perlu melakukan pemesanan kembali sebesar $1.578 .742,75 \mathrm{~kg}$ ketika jumlah persediaan beras mencapai $277.188 \mathrm{~kg}$.

\section{Menentukan Besarnya Biaya Persediaan}

Untuk mengetahui total biaya persediaan beras minimal yang diperlukan perusahaan dengan menggunakan perhitungan EOQ. Hal ini dilakukan untuk penghematan biaya persediaan perusahaan. Untuk menghitung total biaya persediaan digunakan rumus sebagai berikut :

$T I C=\sqrt{2 A P C}$ dimana, TIC : Total Inventory Cost (total biaya persediaan), A : Jumlah kebutuhan beras dalam satu periode tertentu $(\mathrm{kg}), \mathrm{P}$ : Biaya $(\mathrm{Rp})$ setiap kali pemesanan dan $\mathrm{C}$ :Biaya penyimpanan yang dinyatakan dalam persentase dari persediaan ratarata $(\%)$.

a. Gudang Olaya

$$
T I C=\sqrt{2 \times 15.188 .865 \times 150.000 \times 1,38}=R p \cdot 2.507 .626,39
$$

b. Gudang Lawanga

$$
T I C=\sqrt{2 \times 16.490 .846 \times 150.000 \times 1,38}=R p .2 .612 .893,07
$$

c. Gudang Jaya Kencana Toili

$$
T I C=\sqrt{2 \times 11.418 .750 \times 150.000 \times 1,38}=R p .2 .174 .249,87
$$

d. Gudang Galang

$$
T I C=\sqrt{2 \times 11.465 .172 \times 150.000 \times 1,38}=R p \cdot 2.178 .665,00
$$

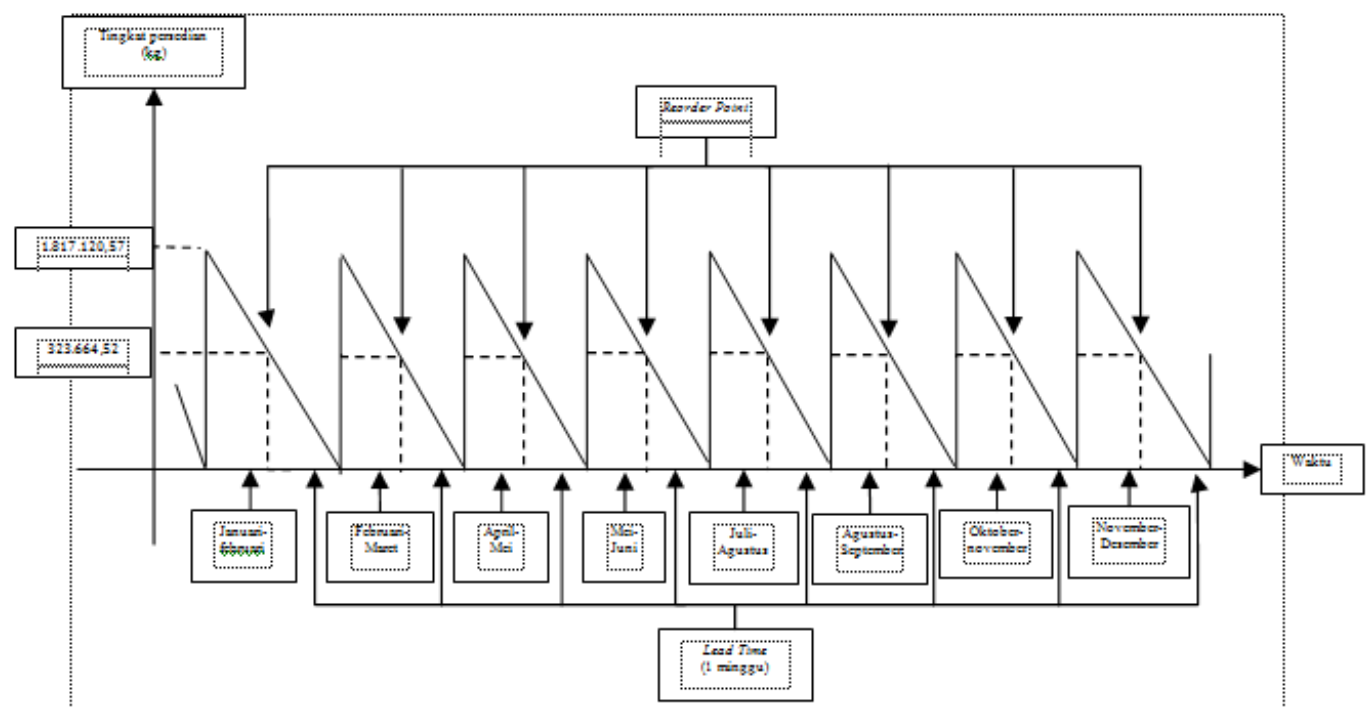

Gambar 2 : Grafik Pengaturan pemesanan kembali (Reorder Point) Gudang Olaya 


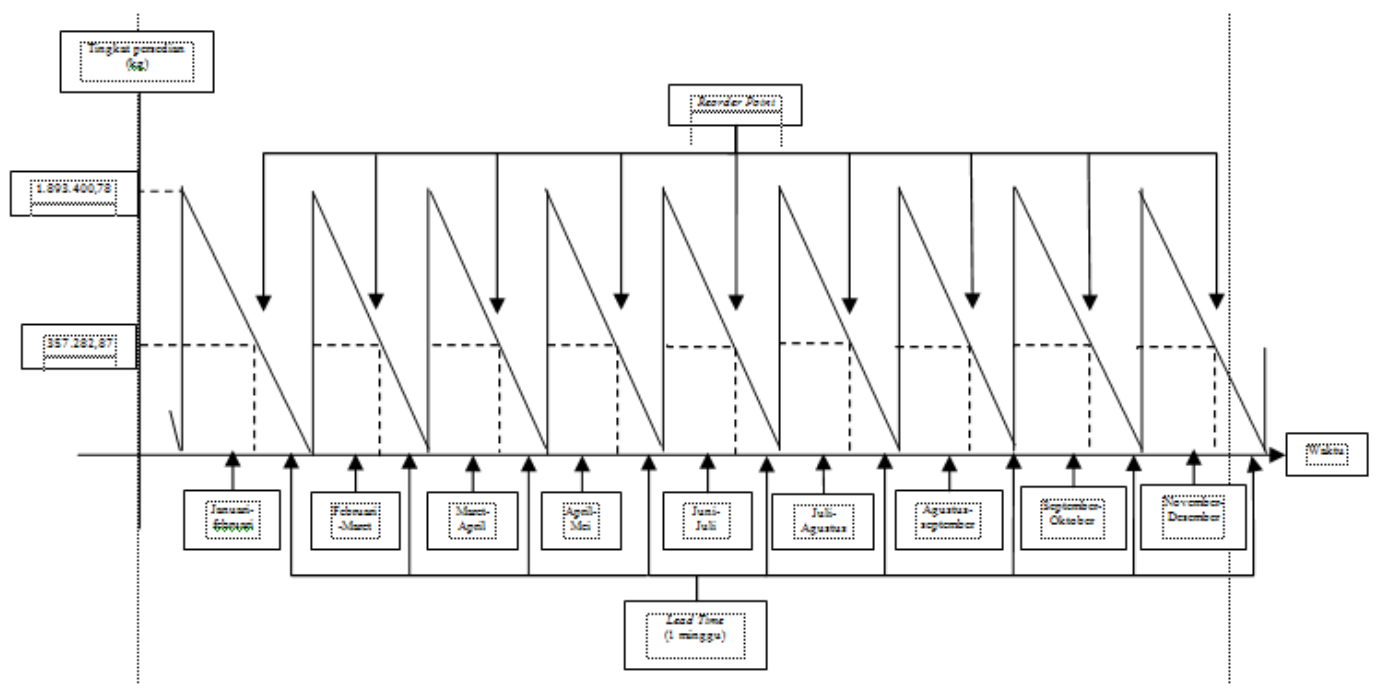

Gambar 3 : Grafik Pengaturan pemesanan kembali (Reorder Point) Gudang Lawanga

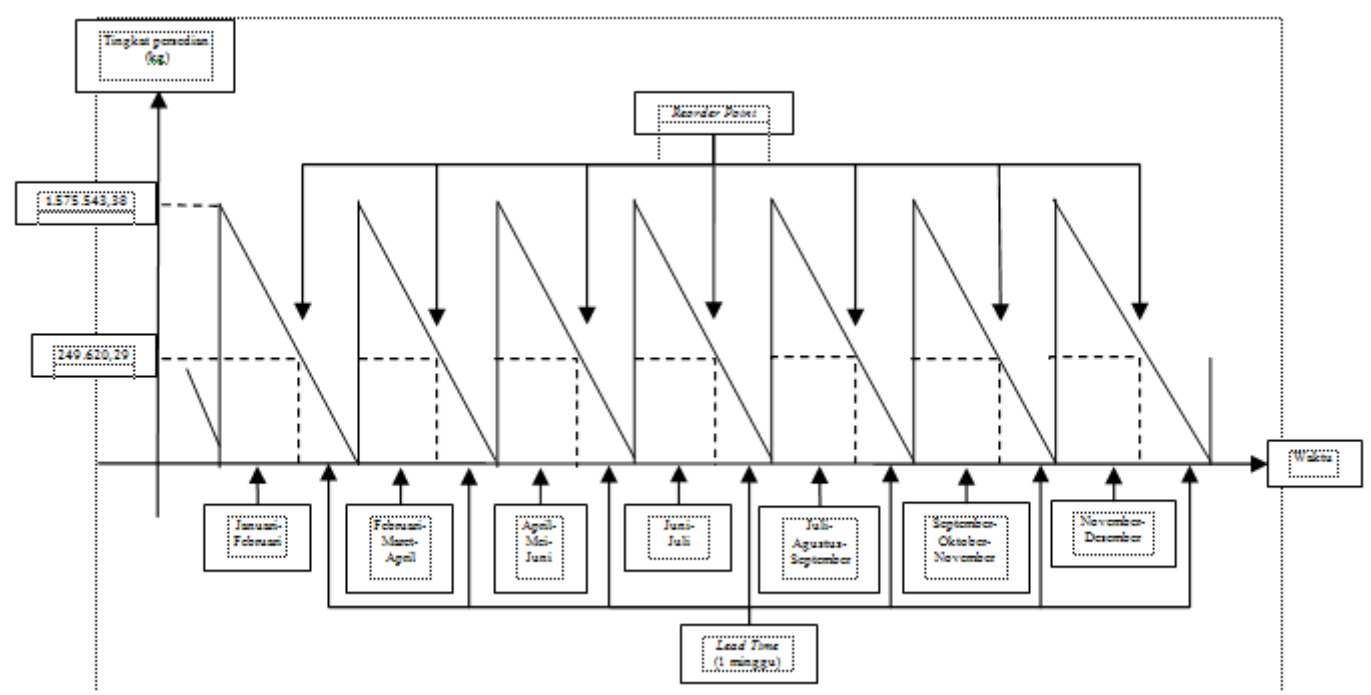

Gambar 4 : Grafik Pengaturan pemesanan kembali (Reorder Point) Gudang Jaya Kencana Toili 


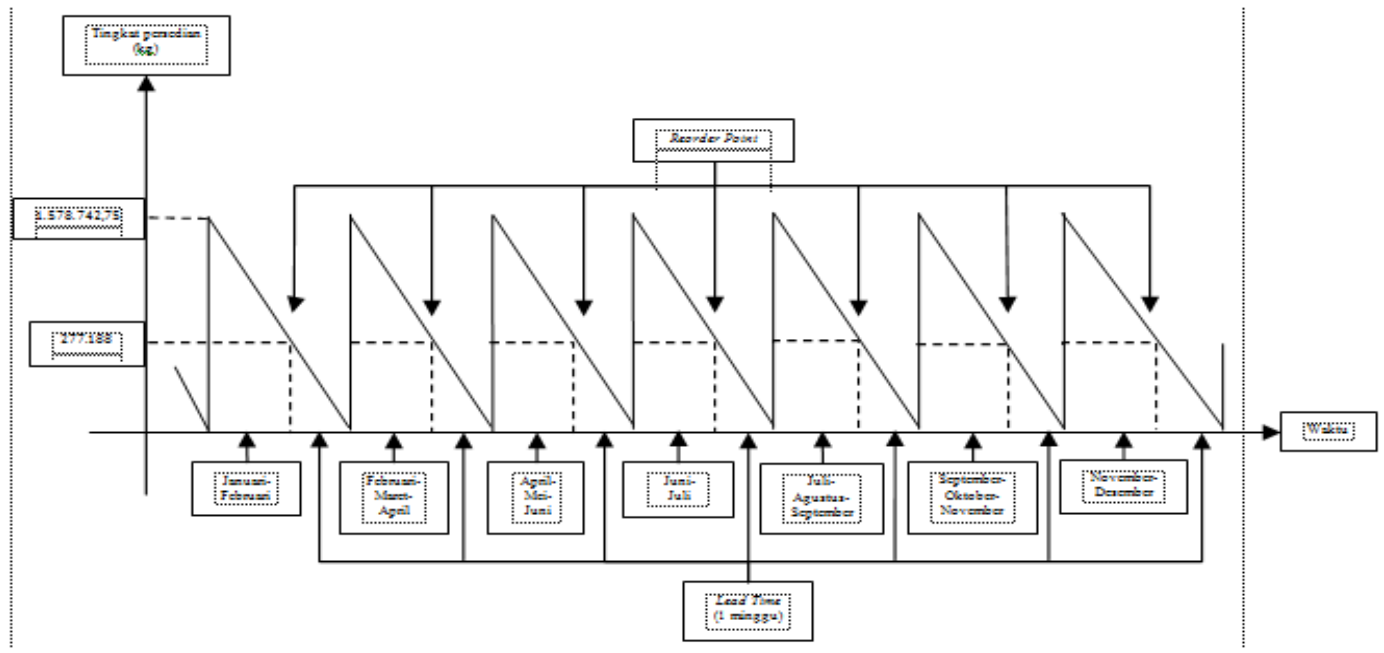

Gambar 5 : Grafik Pengaturan pemesanan kembali (Reorder Point) Gudang Galang

\subsection{Pembahasan}

Berdasarkan analisis data yang telah dilakukan dengan menggunakan metode Economic Order Quantity (EOQ), dimulai dari Pengaturan Persediaan Beras yang ekonomis, Menghitung Persediaan Pengaman (Safety Stock), Menghitung Persediaan Maksimum (Maksimum Inventory), Menentukan Titik Pemesanan Kembali (Reorder Point), dan Menentukan Besarnya Biaya Persediaan dapat dilihat pada table 6 sebagai berikut:

Tabel 10 : Pengaturan Persediaan Menggunakan Metode EOQ (Economic Order Quantity)

\begin{tabular}{|c|c|c|c|c|c|}
\hline NO & Keterangan & Gudang Olaya & $\begin{array}{l}\text { Gudang } \\
\text { Lawanga }\end{array}$ & $\begin{array}{l}\text { Gudang Jaya } \\
\text { Kencana Toili }\end{array}$ & $\begin{array}{l}\text { Gudang } \\
\text { Galang }\end{array}$ \\
\hline 1. & $\begin{array}{l}\text { Jumlah } \\
\text { Pemesanan } \\
\text { Beras } \\
\text { perpesan }\end{array}$ & $1.817 .120,57 \mathrm{~kg}$ & $1.893 .400,78 \mathrm{~kg}$ & $1.575 .543,38 \mathrm{~kg}$ & $1.578 .742,75 \mathrm{~kg}$ \\
\hline 2. & $\begin{array}{l}\text { TotalBiaya } \\
\text { Persediaan/ta } \\
\text { hun }\end{array}$ & Rp. 2.507.626,39 & Rp. 2.612.893,07 & Rp. 2.174.249,87 & Rp. $2.178 .665,00$ \\
\hline 3. & $\begin{array}{l}\text { Frekuensi } \\
\text { Pemesanan }\end{array}$ & $8 \mathrm{kali}$ & $9 \mathrm{kali}$ & $7 \mathrm{kali}$ & $7 \mathrm{kali}$ \\
\hline 4. & $\begin{array}{l}\text { Persediaan } \\
\text { Pengaman }\end{array}$ & $32.371,28 \mathrm{~kg}$ & $41.020,07 \mathrm{~kg}$ & $30.630,61 \mathrm{~kg}$ & $57.307,99 \mathrm{~kg}$ \\
\hline 5. & $\begin{array}{l}\text { Titik } \\
\text { Pemesanan } \\
\text { Kembali }\end{array}$ & $323.664,52 \mathrm{~kg}$ & $357.282,87 \mathrm{~kg}$ & $249.620,29 \mathrm{~kg}$ & $277.188 \mathrm{~kg}$ \\
\hline 6. & $\begin{array}{l}\text { Persediaan } \\
\text { Maksimum }\end{array}$ & $1.849 .491,85 \mathrm{~kg}$ & $1.934 .420,85 \mathrm{~kg}$ & $1.606 .173,99 \mathrm{~kg}$ & $1.636 .050,74 \mathrm{~kg}$ \\
\hline
\end{tabular}


Tabel 11: Pengaturan Persediaan Berdasarkan Kebijakan Perum BULOG Divre Sulteng

\begin{tabular}{|c|l|c|c|c|c|}
\hline NO & \multicolumn{1}{|c|}{ Keterangan } & Gudang Olaya & $\begin{array}{c}\text { Gudang } \\
\text { Lawanga }\end{array}$ & $\begin{array}{c}\text { Gudang Jaya } \\
\text { Kencana Toili }\end{array}$ & $\begin{array}{c}\text { Gudang } \\
\text { Galang }\end{array}$ \\
\hline 1. & $\begin{array}{l}\text { Jumlah } \\
\text { Pemesanan Beras } \\
\text { perpesan }\end{array}$ & --- & -- & --- & -- \\
\hline 2. & $\begin{array}{l}\text { TotalBiaya } \\
\text { Persediaan/tahun }\end{array}$ & $R p .2 .548 .031,68$ & $R p .3 .332 .149,09$ & $R p .2 .225 .437,5$ & $R p .2 .332 .193,73$ \\
\hline 3. & $\begin{array}{l}\text { Frekuensi } \\
\text { Pemesanan }\end{array}$ & 10 kali & 18 kali & 9 kali & 5 kali \\
\hline 4. & $\begin{array}{l}\text { Persediaan } \\
\text { Pengaman }\end{array}$ & --- & --- & --- & -- \\
\hline 5. & $\begin{array}{l}\text { Titik Pemesanan } \\
\text { Kembali }\end{array}$ & --- & -- & -- & -- \\
\hline 6. & $\begin{array}{l}\text { Persediaan } \\
\text { Maksimum }\end{array}$ & --- & -- & - \\
\hline
\end{tabular}

\subsection{KESIMPULAN}

Berdasarkan hasil penelitian yang telah dilakukan, dapat disimpulkan :

1. Jumlah dan biaya Persediaan beras yang ekonomis, dengan menggunakan metode Economic Order Quantity (EOQ) pada Perum BULOG Divre Sulteng yaitu:

a. Jumlah pemesanan yang ekonomis pada Perum BULOG Divre Sulteng untuk Gudang Olaya adalah sebesar 1.817.120,57 kg/pesan, Gudang Lawanga $1.893 .400,78$ kg/pesan, Gudang Jaya Kencana Toili 1.575.543,38 kg/pesan, dan Gudang Galang 1.578.742,75 kg/pesan.

b. Jumlah Persediaan Pengaman pada Perum BULOG Divre Sulteng untuk Gudang Olaya adalah sebesar 32.371,284 kg., Gudang Lawanga 41.020,07 kg, Gudang Jaya Kencana Toili 30.630,61 kg, dan Gudang Galang 57.307,99 kg.

c. Jumlah persediaan maksimum pada Perum BULOG Divre Sulteng untuk Gudang Olaya adalah sebesar $1.849 .491,85 \mathrm{~kg}$, Gudang Lawanga $1.934 .420,85 \mathrm{~kg}$, Gudang Jaya Kencana Toili $1.606 .173,99 \mathrm{~kg}$, dan Gudang Galang $1.636 .050,74 \mathrm{~kg}$.

d. Titik pemesanan kembali pada Perum BULOG Divre Sulteng untuk Gudang Olaya adalah ketika persediaan di Gudang mencapai $323.664,52 \mathrm{~kg}$, untuk Gudang Lawanga adalah ketika persediaan di Gudang mencapai 357.282,87 kg, untuk Gudang Jaya Kencana Toili adalah ketika persediaan di Gudang mencapai 249.620,29 kg, dan untuk Gudang Galang adalah ketika persediaan di Gudang mencapai $277.188 \mathrm{~kg}$. 
e. Besarnya biaya persediaan beras (total inventory cost) Perum BULOG Divre Sulteng tahun 2016 dengan metode EOQ(Economic Order Quantity) yaitu untuk Gudang Olaya adalah sebesar $R p .2 .507 .626,39$, untuk Gudang Lawanga adalah sebesar Rp.2.612.893,07, untuk Gudang Jaya Kencana Toili adalah sebesar $R p .2 .174 .249,87$, dan untuk Gudang Galang adalah sebesar Rp. 2.178.665,00).

2. Efisiensi Biaya persediaan beras Perum BULOG Divre Sulteng tahun 2016 dikomparasikan terhadap biaya pengaturan persedian yang ekonomis dengan metode (EOQ)Economic Order Quantity adalah Gudang Olaya dapat menghemat biaya sebesar $R p 40.405,29$, Gudang Lawanga sebesar $R p .719 .256,02$, Gudang Jaya Kencana Toili sebesar Rp.51.187,63, dan Gudang Galang sebesarRp.153.528,73. Hasil tersebut memberikan implikasi terhadap efisiensi terbesar pada biaya persediaan Perum BULOG Divre Sulawesi Tengah untuk Gudang Lawanga sebesar $22 \%$.

\section{DAFTAR PUSTAKA}

[1] Assauri, S, Manajemen Produksi dan Operasi, Edisi Revisi, Lembaga Penerbitan Fakultas Ekonomi Universitas Indonesia, 1999, Jakarta.

[2] Gitosudarmo, Manajemen Keuangan, Edisi 3,BPFE (Badan Penerbitan Fakultas Ekonomi),1999, Yogyakarta.

[3] Riyanto,B,Dasar-Dasar Pembelanjaan Perusahaan, Edisi 4,BPFE(Badan Penerbitan Fakultas Ekonomi),2001, Yogyakarta.

[4] Trisilawaty, Analisis Optimasi Rantai Pasok Beras dan Penggunaan Gudang Perum BULOG Divre DKI Jakata, Sekolah Pascasarjana, 2011, Institut Pertanian Bogor. 